\title{
Diacronie
}

Studi di Storia Contemporanea

$N^{\circ} 8,4 \mid 2011$

Le sembianze di Clio: approcci alla storia

\section{Historia y Destino: el fatalismo como identidad nacional lusa}

Pablo Javier Pérez López

\section{(2) OpenEdition}

Journals

\section{Edición electrónica}

URL: http://journals.openedition.org/diacronie/3514

DOI: 10.4000/diacronie.3514

ISSN: 2038-0925

\section{Editor}

Association culturelle Diacronie

Referencia electrónica

Pablo Javier Pérez López, « Historia y Destino: el fatalismo como identidad nacional lusa », Diacronie [En línea], № 8, 4 | 2011, documento 3, Puesto en línea el 29 octubre 2011, consultado el 30 abril 2019. URL : http://journals.openedition.org/diacronie/3514; DOI : 10.4000/diacronie.3514 


\section{Diacronie}

\section{Historia y Destino: el fatalismo como identidad nacional lusa}

Pablo Javier PÉREZ LÓPEZ*

Se pretende abordar, desde la perspectiva de la Filosofía de la Historia, la especial relación que parece guardar el pueblo portugués con la facticidad histórica comprendida como fatum. Ello nos permitirá reflexionar sobre la dimensión factual de la historia y la comprensión de la historia vivida y/ o escrita como amor fati en perspectiva local y/o universal.

Es imposible para los hombres acceder a la concepción más alta de la historia universal; el más grande de los historiadores, tanto como el más grande de los filósofos, no será más que un profeta, pues ambos hacen abstracción desde el círculo más interior hacia los demás círculos exteriores.

Friedrich Nietzsche, Fatum $e$ Historia, 1862.

¿Que tem sido a grandeza em história senão a realização de sonhos aparentemente impossíveis, feitos por iluminados precursores que vêem no Além, que lêem no Futuro?

Antero de Figueiredo

Este sonho que sonhei É verdade muito certa, Que lá da Ilha encoberta Vos há-de chegar este Rei.

Bandarra, Sonho Segundo. XV 


\section{Fatalismo, Amor Fati, Eterno Retorno}

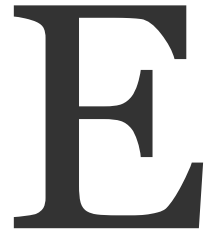

$\mathrm{n}$ pocos pueblos encontramos una encarnación tan profunda del fatalismo como en el portugués. En él, el diálogo, aparentemente paradójico, entre mito e historia, entre historia y destino, entre libertad y profecía se nos ofrece como un lugar propicio para preguntarnos por la facticidad de lo histórico y las perplejidades metafísicas que ésta oculta.

Al descoser la palabra "fatalismo" encontramos primero Fatum, que bien podría encontrar su origen etimológico en el decir latino (for, faris, fatum) siendo así "lo dicho". Lo escrito, lo revelado, lo anunciado, lo pre-dicho, lo pre-visto por una divinidad. Bien puede encontrar aquí lugar la expresión "lo que está escrito". De este fatum proviene el Hado y el Destino y lo "fatal" comprendido como lo inevitable, lo necesario, lo fatídico. Fatal adquirió un tinte negativo relativo a lo lamentablemente irremediable, lo que es dolorosamente inevitable. Qué bien puede situarse aquí la expresión popular "Mortal (fatal) de necesidad”.

En la misma familia de vocablos encontramos inefable (lo que no se puede decir); hada, o hadas (del plural de fatum, fata): los destinos, las hadas (encargadas de revelar los hados), enfadar y por supuesto el Fado portugués comprendido no sólo como el canto popular y profundamente metafísico del pueblo lusíada sino como el propio Destino, la providencia, la fortuna. Incluso encontramos el verbo portugués fadar, comprendido como vaticinar, predestinar. Por último cabe destacar la palabra Fábula, comprendida como habla, habladuría.

Nótese aquí ya, y en su origen etimológico (decir) la dualidad fatalista que acabará por diferenciarse en el doble concepto determinismo-fatalismo. La palabra dicha, el logos, la razón, la necesidad racional versus la voluntad del creador, del Señor, lo previsto por la pro-videncia. El Fadum stoicum es un fatalismo de la razón como lo será el fatalismo propio de los materialistas ilustrados, especialmente Holbach, La Mettrie y Diderot quien expresó esta encrucijada metafísica asociada al Fatum en su novela Jacques, el fatalista.

En todo ello, en el seno de esta palabra está ya sembrada una de las encrucijadas filosóficas más hondas y transitadas desde que el mundo es mundo, la naturaleza, en el caso de existir, del libre arbitrio. La naturaleza de la Libertad, problema hondamente metafísica que está imbricado en la esencia de la pregunta por la ontología de la Historia en su triple dimensión fáctica, óntico-intencional e historiográfica. 
El intento de conciliación entre libertad individual y necesidad racional, divina o histórica, la pregunta por la naturaleza de la libertad, está presente en todas las etapas filosóficas y también muy especialmente en el seno del irracionalismo del siglo XIX, nótese la importancia de esta temática en Arthur Schopenhauer ${ }^{1}$. Y es que el problema de la naturaleza de la libertad enfrentada al determinismo o al gobierno dictatorial del Destino está incrustado en el seno del pensar de lo trágico y del pensar trágico (también podría llamarse poético-mítico), su aceptación de nuestra doble naturaleza² .

Pero más allá de la profunda dimensión filosófica que implica y de sus incontables vericuetos, aceptemos provisionalmente como fatalismo aquella concepción que sostiene que todos los acontecimientos de la historia y del mundo y en buena medida las individuales están determinadas por el destino.

En este sentido bien podría proponerse un acercamiento entre el fatalismo y el amor fati propio del pensar trágico nietzscheano. La concepción según la cual el universo nace y perece cíclicamente es tan antigua como el tiempo. Tanto el hinduismo como el budismo. Heráclito, los pitagóricos o el averroísmo medieval árabe exhibieron esta doctrina en sus diferentes versiones, pero parece haber sido Nietzsche quien con más fuerza aceptó y recuperó la teoría de los ciclos temporales en su mito regulador denominado eterno retorno. En un mundo con átomos indestructibles y finitos sus infinitas combinaciones en la eternidad del tiempo darán lugar a un número infinito de mundos y por tanto de momentos iguales. Se trata de "una profecía", un mitologema regulador que supone la liberación de la moralidad subyugante y la aceptación del amor al destino. El hombre trágico acepta el mundo como un eterno retorno de lo mismo, como una eternidad impuesta a la vida y repetida recurrentemente. Esto implica una concepción nueva del hecho histórico, un fatalismo positivo que acepta el destino y la historia como un recurrente y cíclico devenir ya definido y cíclicamente establecido.

$\mathrm{Y}$ todo en el contexto de la aceptación, en términos unamunianos, del portugués como uno de los pueblos donde se encarna el sentimiento trágico de la vida comprendido esencialmente como la aceptación fatal de la lucha entre la Razón y la Vida. En buena medida la dimensión filosófica inherente al fatalismo está en el seno de la filosofía trágica.

\footnotetext{
${ }^{1}$ Cfr. SCHOPENHAUER, Arthur, Parerga y Paralipómena, v. II, Málaga, Ágora, 1997, Especulación trascendente sobre la aparente intencionalidad en el destino del individuo, pp. 91-120. SCHOPENHAUER, Arthur, Sobre la libertad de la Voluntad, Madrid, Alianza, 2004. ${ }^{2}$ «O homem pensa como espírito, e procede como animal. A liberdade e a fatalidade em guerra aberta! Eis a dôr e a origem da alegria. A dôr - fatalidade criando a liberdade - alegria, o animal gerando o espírito». PASCOAES, Teixeira de, Verbo Escuro, Paris-Lisboa, Aillaud e Bertrand, 1915, p. 128.
} 
Dos elementos claves de la identidad portuguesa, integran y articulan esta visión nítidamente religiosa y fatalista de su propia historia, de su propio devenir o destino colectivo. Ambas pueden comprenderse en el seno del pensar y el sentir trágico propio de la identidad de un pueblo. Se trata del Sebastianismo y del Saudosismo, que sólo pueden comprenderse conectados ${ }^{3}$.

\section{Sebastianismo}

El Sebastianismo supone un mesianismo-profetismo. Un tipo de mesianismo aparentemente secularizado, de fe ciega en un líder, un enviado político-religioso que llegará para inaugurar una nueva era de prosperidad y bienestar. Un Mesías, un enviado de Dios. Debe comprenderse en el contexto del milenarismo ${ }^{4}$ y del joaquinismo ${ }^{5}$ que suponen tanto la idea de un reino de Cristo ejercido directamente por un rey cristiano como la introducción en la historia de cierto progreso y con ello de cierta pre-decibilidad. La idea de un rey justo y piadoso que acabaría con el dominio de otomanos y otros pueblos musulmanes estableciendo un reino de paz y justicia en la tierra.

El Joaquinismo llegó a la península ibérica en el seno del profetismo y las profecías rimadas del siglo XV. Penetró rápidamente en Portugal donde el racionalismo aún no había anidado y no tanto en España donde el mesianismo nunca llegó a tener la misma importancia. El sustrato celta del pueblo portugués así como el semítico y el gnóstico canalizaron y favorecieron esta suerte de milenarismo mesiánico protagonizado por el rey D. Sebastião I de Portugal.

D. Sebastião, 1554-1578, decimosexto rey de Portugal, séptimo Rey de la dinastía de los Avis, Nieto de João III, de quien heredó el trono con tres años bajo la regencia de su

\footnotetext{
3 «4. O movimento saudosista e a sua base sebastianista. O saudosismo está criando a base intelectual e moral ao sebastianismo, puramente popular.». PESSOA, Fernando, Sobre Portugal - Introdução ao Problema Nacional, Lisboa, Ática, 1979, p. 176.

${ }^{4}$ El milenarismo afirma que Cristo volverá, antes del último combate contra el Mal, para gobernar sobre la Tierra durante mil años. El Apocalipsis (20:4-5) revela que el diablo permanecerá encarcelado en el abismo por mil años. Algunos teóricos políticos o sociológicos han subrayado la importancia del modelo milenarista en construcciones utópicas propias del socialismo o el comunismo, especialmente en el siglo XIX. Este utopismo secular tendría así su origen en estas primeras utopías apocalípticas del cristianismo primitivo.

${ }^{5}$ Joaquinistas fueron los seguidores del Abad italiano Joaquín de Fiore. Promovió una nueva interpretación de la historia y sus edades. Influyó entre grupos heterodoxos y heréticos. Su profetismo distingue entre la primera edad, la edad del padre o la Antigua alianza, la segunda; la edad del hijo, la del mundo cristiano y por último la tercera, la del Espíritu Santo, la del Evangelio Eterno. Esta etapa supondrá, según sus profecías, la superación de la jerarquía de la Iglesia y la instauración de una Iglesia del espíritu fundada en la igualdad y el utopismo monástico.
} 
abuela Catarina de Austria, fue apodado primero o desejado, por ser el heredero esperado de la dinastía de los Avis y después o encoberto por el tema que aquí nos ocupa.

De espíritu religioso y gran fervor militar se envolvió en una gran batalla, la ya inmortal confrontación de Alcazarquivir, en Marruecos después de haber recibido la solicitud de ayuda de Abu Abdallah Mohammed II Saadi, cuarto sultán de Marruecos de la dinastía Saadi para recuperar el trono. La batalla es conocida como la batalla de los tres reyes pues en ella perecieron tres monarcas implicados, Abd Al-Malik, sultán de Marruecos apoyado por tropas otomanas, el ya citado pretendiente y el propio Don Sebastião. El ejército del Rey Don Sebastião estaba formado por 9000 portugueses, 3000 alemanes, 2000 castellanos, 600 italianos y cientos de nobles portugueses. La caída de D. Sebastião y su aparente fenecimiento supuso el fin de una época de esplendor (iniciada en la batalla Aljubarrota ${ }^{6}$ ) pero sobre todo la pérdida de la independencia y la irremediable anexión a Castilla por parte de Felipe II tras la crisis dinástica de 1580.

Parece que nadie vio morir al Rey. (al menos eso dice la leyenda), y que se sólo se recuperó un cadáver desfigurado. Algunos testimonios hablan de que después de la batalla algunos sirvientes del Rey encontraron su cuerpo en medio del campo repleto de cuerpos. Su rostro al parecer se encontraba desecho e irreconocible. Algunos nobles portugueses fueron llamados por el rey de Marruecos para que confirmasen la identidad del cuerpo. Después Muley Hamet les ofreció una mula para cargar el cuerpo hasta Tánger y después Ceuta. ${ }^{7}$

\footnotetext{
${ }^{6}$ Acaecida el 14 de Agosto de 1385 significó la victoria sobre Castilla, la consolidación de la identidad nacional y la afirmación de la alianza con Inglaterra y el inicio de una era de esplendor culminada con los Descubrimientos. (As Descobertas).

${ }^{7}$ Desde una perspectiva historiográfica parece poder documentarse la muerte de D. Sebastião. Según algunos documentos su cuerpo fue recuperado gracias a su mozo de cámara. Buena parte de los nobles supervivientes (apenas unos cientos) lo reconocieron. Salvar la vida habiendo perecido el rey sería considerado así una vergüenza según el código de caballerías y explicaría el por qué del silencio de muchos testigos. El Muley Hamet custodió su cuerpo, cuerpo que parecía de gran importancia para Felipe II. Algunos documentos presentes en el Archivo General de Simancas y recientemente transcitos por RIVAS CALVO, Emilio, D'ABREU, Carlos, «Alcazarquivir. El enigma (o el rescate del rey don Sebastián)», en Praça Velha, 21, Julho 2007, pp. 39-59 parecen certificar la entrega del cuerpo. Cfr. AGS 1578, Acta de Entrega do Corpo de D. Sebastião. Sección EST/NPO-01, Legajo 396, Ceuta, 1578.XII.10.

Desde esta perspectiva alejada de la leyenda, la cruzada emprendida por Sebastián I, puede considerarse un movimiento suicida propio de un militar sin experiencia. Gran parte de los jóvenes de la época murieron en la batalla y los más preparados nobles. Además supuso una pérdida importantísima para la Hacienda portuguesa no sólo por el coste militar sino por el derivado de los posteriores rescates. La inscripción del túmulo de Sebastian, sito en el Mosteiro dos Jerónimos de Lisboa invita al enigma, pero una prueba de ADN (ya reclamada por varios historiadores) acabaría con todas las dudas pero quizá también con uno de los mitos
} 
Varias son las hipótesis sobre el desaparecido Rey. Algunas de ellas incluso sitúan su tumba en Francia, donde el Rey encubierto habría vivido en un monasterio en Limoges.

Manuel J. Gandra ${ }^{8}$ se apoya en un texto de Hubert Texier de principios de siglo. Según estos datos, una medalla con la inscripción Sebastianus primus Portugaliae rex, fue encontrada en el citado monasterio agustino en el túmulo de piedra de una osamenta bien conservada probaría la presencia y muerte de Sebastián I en Francia.

El deseo de su regreso, de que no estuviese muerto, de que volviese y con él el antiguo esplendor del Reino hizo que su figura se mitificara, se negase su muerte y apareciesen al menos cuatro pseudo-Sebastianes que reclamaban la identidad del misterioso Rey 9 .

Especialmente literario parece el caso del llamado pastelero de Madrigal, Gabriel de Espinosa. Y quizá el más serio de estos aparecidos fue el de Venecia, precisamente por haber profetizado João de Castro su llegada en esta ciudad italiana.

El carácter profético del sebastianismo muestra cómo la profecía es una tentativa de penetrar en los misterios de la divina providencia, siguiendo a Antonio Vieira, Dios

embrionarios de la identidad portuguesa que parece fundarse en la aceptación de la locura y el destino.

8 HUBERT, Texier, Pesquisas históricas sobre Sebastião I, Rei de Portugal (Paris, 1904) ou de como o Desejado morreu no exílio, em Limoges (tradução, notas e foto de Manuel J. Gandra).

URL: < http://www.cesdies.net/quinto-imperio-e-sebastica/fsp/Texier\%2otraducao.pdf/ > [consultado el 15/10/2011].

${ }^{9}$ «Mas era verdade que D. Sebastião morrera? Ninguém o vira morrer. É verdade que os Mouros entregaram o corpo do rei defunto a Filipe II e que este o faz sepultar no Mosteiro dos Jerónimos (1582). Mas muitos tinham as suas dúvidas acerca da identidade do corpo, e viamnas confirmadas pelas palavras do epitáfio: si vera est fama... Surgiram quatro aventureiros, que se diziam ser D. Sebastião: dois em Portugal e dois fora do país. O primeiro foi «o rei de Penamacor», que foi preso, exposto no pelourinho e condenado às galés (1584). O segundo foi «o ermitão da Ericeira», que apareceu no ano seguinte e foi executado em Lisboa. O terceiro foi um antigo soldado castelhano, Gabriel de Espinosa, que se estabelecera em Madrigal (Castela) onde, num convento, vivia D. Ana, filha ilegítima de D. Juan de Áustria. Ela tinha um confessor português, o agostinho Frei Miguel dos Santos, que a convenceu de que o antigo soldado, agora pasteleiro, era D. Sebastião. A intriga foi descoberta: Gabriel de Espinosa e o monge foram executados (1595) e a princesa foi transferida para um mosteiro em Ávila, onde a esperava uma rigorosa vida claustral. O quarto e o mais célebre foi o calabrês Marco Túlio Catizzone, que apareceu em Veneza (1598), onde foi visitado por diversos Portugueses, entre outros por D. João de Castro, que o homenageou como seu soberano. Depois de muitas aventuras, o impostor foi executado em San Lúcar (1603).

Dos quatro Pseudo-Sebastiães, cuja história aqui só tocámos de leve 36, apenas o Calabrês se integra na história do sebastianismo, porque, devido sobretudo à imaginação exaltada de D. João de Castro, foi identificado com o Encoberto das profecias nacionais, o que não consta dos três outros. O pasteleiro de Madrigal não passou de marioneta nas mãos de Frei Miguel dos Santos, que, muito provavelmente, se queria servir dele para suscitar uma revolta em Portugal a favor de D. António, o Prior do Crato. Os dois outros agiram por conta própria, mas a boa acolhida que esses aventureiros receberam de muitos populares prova que o povo tinha saudades de um rei nacional». VAN DEN BESSELAAR, José, O sebastianismo. História sumária, Lisboa, Instituto de Cultura e Língua Portuguesa, 1987, p. 62. 
reveló sus designios históricos a través de sus profetas ${ }^{10}$. Ese núcleo de la profecía, tan próxima al sebastianismo y por ende al fatalismo luso, es irreductible a la Racionalidad, tiene un núcleo mítico que muestra cuán poderoso puede llegar a resultar el mito como motor del proceso histórico y cómo la aceptación de la historia como interpretación ${ }^{11}$ deja lugar al exégeta como una suerte de interpretador de signos, de lector cabalístico.

Los sebastianistas eruditos coleccionaban profecías en una suerte de catálogos que recibían el nombre de cartapacios ${ }^{12}$. Las profecías primeras que en el seno del núcleo semítico fundan este providencialismo son principalmente las formuladas por Isaías y Ezequiel.

Los sebastianistas acuden a las profecías de Nostradamus pero sobre todo al zapatero de Trancoso: Bandarra. Es Bandarra el profeta por excelencia de Portugal. Nótese qué bien expresa Fernando Pessoa su importancia para una comprensión de la identidad portuguesa en perspectiva providencialista y fatalista. ${ }^{13}$

La imagen de Sebastián fue rehabilitada y mitificada. Se trataba de un hombre que habría de cubrir su identidad, un enmascarado ${ }^{14}$ que vagó por los desiertos, que había recalado en una isla desierta y misteriosa (especialmente los sebastianistas del siglo XVIII imaginaban a D. Sebastião en esta isla remota, una nueva Atlántida quizá). Fue

${ }^{10}$ «O primeyro motivo, \&muy principal, porque Deos coftuma revelar as couías futuras (ou fejão beneficios, ou castigos) muyto tempo antes de fuccederem, he para que conheçaõ clara, \& firmemente os homens, que todas vem difpenfadas por fua mão». VIEIRA, António, Historia do Futuro, Livro Anteprimeyro, Lisboa, Galram, 1718, p. 38

${ }^{11}$ Algunos teóricos de la historia encontrarán en esta expresión cierta familiaridad con la verdad histórica freudiana.

${ }^{12}$ Cfr. BNP [Biblioteca Nacional de Portugal]/ R. Cod- 627. Profecias de muitos servos de Deos N. S. profetizando a fundação do Quinto Imperio do Senhor na pessoa do seo fundador admiravel. Reunidas de muitos originais impressos e manuscritos em Lisboa [Manuscrito]. URL: < http://purl.pt/14780 > [consultado el 15/10/2011].

13 «O verdadeiro patrono do nosso País é esse sapateiro Bandarra. Abandonemos Fátima por Trancoso.

Esse humilde sapateiro de Trancoso é um dos mestres da nossa alma nacional, uma das razões de ser da nossa independência, um dos impulsionadores do nosso sentimento imperial.

Esse Bandarra é a voz do Povo português, gritando, por cima da defecção dos nobres e dos clérigos, por cima da indiferença dos cautos e dos incautos, a existência sagrada de Portugal.

Quando António Vieira quis basear em qualquer coisa a sua fé natural nos destinos superiores da Pátria, que coisa foi a que encontrou? As profecias desse sapateiro de Trancoso Amou-as e as comentou o maior artista da nossa terra, o Grão-Mestre, que foi, da Ordem Templária de Portugal.

O Bandarra, símbolo eterno do que o Povo pensa de Portugal.

Que Portugal tome consciência de si mesmo. Que rejeite os elementos estranhos. Ponha de parte Roma e a sua religião. Entregue-se à sua própria alma. Nela encontrará a tradição dos romances de cavalaria, onde passa, próxima ou remota, a Tradição Secreta do Cristianismo, a Sucessão Super-Apostólica, a Demanda do Santo Graal. Todas essas coisas, necessariamente dadas em mistério, representam a verdade íntima da alma, a conversação com os símbolos, [...]». PESSOA, Fernando, Sobre Portugal - Introdução ao Problema Nacional, Lisboa, Ática, 1979. p. 177.

${ }^{14}$ Nótese la enorme dimensión simbólica de este hecho para la aceptación de D. Sebastião como personaje esencial de la Tragedia Lusa. 
idealizado como un héroe de novela de caballerías, convirtiéndose en una suerte de Quijote portugués. Varias tragedias y obras de teatro lo tomaron como encarnación de sus argumentos. Especialmente relevante en este sentido parece Traidor, inconfeso y mártir (1849) de José Zorrilla.

El sebastianismo, como movimiento religioso y espiritual se instaló incluso en el norte de Brasil, especialmente en el momento en el que los holandeses amenazaban el dominio portugués del nordeste durante el reinado de Felipe IV.

Durante el gobierno del Marqués de Pombal los sebastianistas fueron perseguidos y también censuradas en buena medida las trovas de Bandarra. Antes de disiparse su fuerza espiritual estuvo muy presente contra los franceses en época napoleónica. El mito sebastianista tiene un poderoso enraizamiento judaico, bíblico, cristiano, céltico y pagano en el insconsciente colectivo portugués. Sebastianistas fueron Almeida Garret, Lopes Vieira, Correia de Oliveira, Mário Beirão y el propio Teixeira de Pascoaes y el núcleo de la Renascença Portuguesa saudosista. Suyas son estas palabras: "O Sebastianismo é a expressão divina, mítica da nossa dor, e ainda em sombra nocturna, o futuro sol da Renascença" ${ }^{15}$. Incluso los acontecimientos históricos de Portugal más cercanos en el tiempo pueden comprenderse o interpretarse en clave sebastianista. Son buenos ejemplos la figura de Sidónio Pais ${ }^{16}$ y quizá la Revolución de los claveles de Abril del 1974 donde los llamados "Capitanes de Abril” parecen envueltos en un claro halo mesiánico.

Esta concepción que nace del providencialismo y el fatalismo se desliga de la concepción positivista, materialista y científica de la historia para, en línea con Carlyle o Emerson colocar la inspiración y la fuerza del individuo concebido en conexión con la divinidad en una aceptación de la unión de lo material y lo espiritual, lo humano y lo divino. En esa perspectiva nacen los héroes y los genios. En la perspectiva pessoana (que merecería un estudio a parte) y la dimensión pagana del sebastianismo, el Destino estaba siempre por encima de todos los dioses convertido en Rey del mundo e igualador de Hombres y Dioses convertidos en hijos de una misma raza. (De ahí su recurrente cita de Píndaro.)

\footnotetext{
${ }^{15}$ PASCOAES, Teixeira de, Arte de ser português, Lisboa, Delraux, 1978, p. 139.

16 Sidónio Pais, 1872-1918. Militar y politico portugués fue presidente de la República portuguesa y conocido como el Presidente-Rey. De tendencia republicana, masón, se hizo con el poder con un golpe de Estado en 1917. Fue asesinado en un atentado en 1918. Encarnó otro de los tradicionales desvaríos mesiánicos en su intento revolucionario y dictatorial. Y por ello fue visto desde la perspectiva sebastianista por no pocos intelectuales, entre ellos el propio Fernando Pessoa. Recuérdese su poema sebastianista À memória do Presidente-Rei Sidónio Pais.
} 


\section{Saudosismo}

Saudade, ha sido, es y será, el corazón y la tripa del alma portuguesa. No es sólo una palabra, sino una cicatriz, quizá la cicatriz de una batalla, una batalla que no se sabe muy bien si ganada o perdida está presente en la piel y en la mirada de un pueblo. La batalla de un destino buscado. ${ }^{17}$ Es palabra, y como toda palabra intraducible, cicatriz de un algo difícilmente aprehensible por el concepto. Esta aparente intraducibilidad conceptual hacia otras lenguas terráqueas, hace de la Saudade emblema identitario de un pueblo, de sus misterios y sus secretos íntimos y a la vez y paradójicamente públicos. Ya el Rey filósofo D. Duarte en el siglo XIV ofreció una primera referencia sobre la predominancia del sentir frente a la racionalidad de esta particular palabra: "A suidade nom descende de cada uma destas partes, mas é um sentido que vem da sensibilidade e não da razão» (Capítulo XXV, Leal Conselheiro), y de su particularidad e intraducibilidad: «E porem me parece este nome de ssuydade tam proprio que o latym nem outra linguagem..nom he pera tal sentido semelhante.» (Rei D. Duarte. Leal Conselheiro. Cap. XXV). Palabra, que en sus diferentes formulaciones arcaicas ${ }^{18}$ (Soedade, soìdade, suïdade) proviene siempre de la "soledad" latina ${ }^{19}$ ("solitas") y que tuvo (tiene) su par en castellano: "soledades"20. Así, este sentimiento dulce y a la vez amargo es un sentir la soledad ${ }^{21}$, la ausencia, la falta de lo deseado o rememorado presente y futuro. «Amor e ausencia são os pais da saudade» nos dijo D. Francisco Manuel de Mello, coetáneo de Quevedo, con alevosa rotundidad. Y es que en definitiva la Saudade no es sino la ausencia de la presencia o mejor aún, la presencia de la ausencia.

\footnotetext{
${ }^{17}$ «Cualquier destino, por largo y complicado que sea, consta en realidad de un solo momento, el momento el que el hombre sabe para siempre quién es.». BORGES, Jorge Luis, El Aleph, Madrid, Alianza, 2003, p. 65.

18 «Saudade y saudoso, nacieron también entre los desheredados y sólo poco a poco, como el propio Fado, fue adoptado por las élites de la sociedad portuguesa: "Saudade e saudoso, primitivamente portuguesas, foram subindo, pouco a pouco, da boca de semi-cultos, às camadas sociais superioes, dos verdadeiros letrados"». MICHAËLIS, Carolina, A Saudade portuguesa, Lisboa, Guimarães editora, 1996, p. 45.

19 «Soedade, soìdade, suïdade, sempre contaram na poesia arcaica por quatro sílabas, correspondentes às do latim solitates, de que saíram, por evoluções fonéticas normais [...]». Ibidem, p. 44

${ }^{20}$ «Soledad em castelhano teve e tem, de facto, e de direito, todas as acepções da antiga suidade e da solidão moderna: sítio ermo; falta de companhia; carencia de uma pessoa que carinhosamente nos sirva de amparo e alivio». Ibidem, p. 57. Véase en este sentido el poemita popular medieval: «iSoledad tengo de ti,/Oh tierra do nací!».

21 «Soedade designava um lugar ermo; o estado da pessoa que está só ou solitária sem companhia, quer no meio do mundo, quer apartada do mundo. Mas também significava isolamente, em abastracto». Ibidem, p. 54.
} 
Presencia de la Ausencia ${ }^{22}$, memoria, voluntad de regreso tal que esa soledad que se siente, esa ausencia que se siente de lo deseado recibe lo deseado no sólo en recuerdo sino en presencia óntica destruyendo todas las reglas del tiempo y el espacio, rememorándolo mitológicamente, hasta re-crearlo. El pasado se reinventa al recordarlo. El tiempo perece.

Esa soledad que se siente de lo ausente, entonces, sólo entonces, acaba por convertirse en una Soledad poblada. Repleta de otros seres pasados y futuros que a fuerza de deseaos acaban por nacer de nuevo en Nosotros. Esta presencia de lo lejano, el dolor y la alegría, pero sobre todo el padecer, el pathos, con su doble valor de pasión y de dolor están indudablemente en el seno de lo saudoso. Un dolor por la "proximidad de lo lejano" que Heidegger, a propósito del Zarathustra de Nietzsche también reconoce en el seno de la Sehnsucht alemana:

Para el que pasa y, de un modo total, para aquel que como maestro tiene que mostrar este paso, para Zaratustra mismo, el adónde está siempre en la lejanía. Lo lejano permanece. En tanto que permanece, permanece en una proximidad, es decir, en aquella que conserva lo lejano como lejano al pensar en lo lejano y en dirección a lo lejano. La proximidad a lo lejano, que conmemora lo lejano, es lo que nuestra lengua llama nostalgia (Sehnsucht). Erróneamente enlazamos la palabra «Sucht» con «suchen» y con «ser arrastrado». Pero la vieja palabra «Sucht» significa: enfermedad, padecimiento, dolor. La nostalgia es el dolor de la proximidad de lo lejano ${ }^{23}$.

Así pues si la Saudade es un sentirse solo, un saberse solo, un sentir-pensar-cantar la soledad pero paradójicamente celebrando la presencia de lo ausente, de lo otro que fui y que seré en el pasado y el futuro, esta soledad cantada, acaba por mutar hacia una soledad de la infancia, una soledad muy poco solitaria. La Saudade en definitiva es una soledad habitada. Y todo porque como bien sabía Pascoaes, la presencia está hecha de ausencias y la saudade que uno deja acaba por convertirse en su presencia verdadera: «A presença do homem é feita de ausências... O homem é, para si próprio, a sua mais

\footnotetext{
${ }^{22}$ «O desejo é a parte sensual e alegre da Saudade, e a lembrança representa a sua face espiritual e dolorida, porque a lembrança inclui a ausência de uma coisa ou de um ser amado que adquire presença espiritual em nós». PASCOAES, Teixeira de, Arte de ser português, cit, p. 94.

${ }^{23}$ HEIDEGGER, Martin, ¿Quién es el Zaratustra de Nietzsche?, en Conferencias y artículos, Barcelona, Ediciones del Serbal, 1994, p. 80. Sobre el mismo parecer véase: «Infancia aprender-primera magia. Donde quiera que haya nostalgia, se siente una pérdida, pero también una sensación de otro tiempo a medias recobrada», NIETZSCHE, Friedrich, Fragmentos Póstumos, vol. II, Madrid, Alianza, 2008, p. 461.
} 
íntima saudade... [...] A saudade que eu deixar, será a minha presença verdadeira. Eu e tudo o que eu amo, seremos nela, uma só criatura» ${ }^{24}$.

Es por todo ello por lo que el pueblo de la Saudade funda una lógica paradójica de estirpe heraclítea donde todo y nada son reversibles e intercambiables. Hacerse ausencia, teatro-nada por donde se hacen presentes los ausentes, los que fueron, los que no son y los que serán ("Somos lo que no somos" dice Pessoa). Lo real y lo imaginario en el seno del pensar poético, del pensar trágico del que el fado es la expresión musical, se confunden y se abrazan. La excesividad portuguesa es así una excesividad de nada, un deseo voraz de ausencia aceptando el ser como una gran ficción vacía $^{25}$, como un gran teatro vacío por el que pasan todos los que han sido y serán en la realidad y en la imaginación. Por todo ello lo uno y lo múltiple, identidad y alteridad se hacen indistinguibles, por ello el uno y el absoluto, el individuo y el todo se unen y la despersonalización literaria, la máscara trágica habita y redime. Todo ello en una nueva religiosidad pagana, en una refundación mítica de la existencia ligada al profetismo y el mesianismo. Todo nacido de una estirpe muy particular de idealismo, un idealismo saudoso $^{26}$, un deseo de lo imposible en la tierra, un imponer la eternidad a la vida, un misticismo materialista de inspiración griega como el mostrado por el maestro Caeiro.

Es, cualidad esencial, metafísica del pueblo portugués la excesividad, véase con qué claridad nos dicen esto Pascoaes y Pessoa:

A História de Portugal é uma tragédia infindável, escrita pela Loucura e pelo Fado: a tragédia do Excesso que nos eleva e precipita de encontro à realidade, e a tragédia da Embriaguez saudosa que nos arrasta a cambalear para a morte. É a tragédia do Tédio bebendo até ao suicídio... a tragédia dos povos inconformáveis e idealistas... A História de Portugal é uma tragédia infindável, no mais belo cenário que Deus fez. Mas daí sua grandeza e o sonho de redenção que germina nas fragas de todos os Calvários... Por isso, a Dor, síntese do Amor e da Morte, é a própria essência da Poesia lusitana. As lágrimas duma Pátria caem sempre no coração dos seus poetas, para que eles as redimam nos seus cantos. Todo o canto é redentor. A eterna angústia do mundo é eternamente redimida nas canções dos Poetas. Assim no

\footnotetext{
${ }^{24}$ PASCOAES, Teixeira de, Verbo Escuro, op.cit, p.33, 97.

${ }^{25}$ "Heráclito tendrá eternamente razón al decir que el ser es una ficción vacía. El mundo "aparente" es el único: el "mundo verdadero" no es más que un añadido mentiroso..." NIETZSCHE, Friedrich, Crepúsculo de los Ídolos, Madrid, Alianza, 1979, p. 45.

${ }^{26}$ «O idealismo saudoso, no qual se fundem o espírito e a matéria, a vida e a morte, é o nosso próprio misticismo» PASCOAES, Teixeira de, Arte de Ser português, op.cit, p. 91.
} 
Lirismo lusíada, se redimem as lágrimas dos lusitanos, nascidas da névoa originária, em que aparece a nossa alma saudosa e aventureira: sebastianista... ${ }^{27}$

A excessividade - a aspiração desmedida porém lucida, a ansia indefinida tendendo constantemente para nunca se deixar definir - constitue o characteristico distinctivo do povo portuguez, o que elle é essencial -, profundamente. Entendamo-nos bem quanto a esta excessividade. Todos os povos são naturalmente excessivos nas qualidades que os distinguem; mas isso é, não porque sejam excessivos, mas porque teem essas qualidades distinctivamente, accentuadamente, e porisso as teem frequentemente em excesso. A excessividade do portuguez é, porém, excessividade vazia, só excessividade, excessividade pura. O povo portuguez não tem qualidades: tem só excessividade. O temperamento portuguez é a falta de um temperamento; e, além d'isso, é excessivo. O portuguez é plastico, amorpho, indefinido, incerto. Só tem de seu o não ter nada de seu; além d'isso tem o excesso. $O$ excesso de que afinal? O excesso de nada, o puro excesso, o excesso de siproprio, da abstracção de ser. Todo o iberico é, emverdade, essencialmente excessivo; porém o hispanhol é-o exteriormente, na expressão apenas (de onde a sua exaggeração notavel), o portuguez é-o, sobretudo, interiormente. Exaggeramos menos nas palavras que o hispanhol typico; é nos sentimentos que somos typicamente desmedidos. Qual é a causa d'este temperamento? Não sei. O não se saber a causa real de nada é umdos encantos da sciencia. Porventura a nossa situação ao mesmo tempo absolutamente meridional e absolutamente atlantica, o nosso sudoestismo absoluto, o explicaria. Se a explicação não é esta, é sem duvida qualquer outra. Sendo assim organicamente excessivos e desmedidos, resulta que, estando á vontade só no excessivo, só no excessivo, onde os outros se desequilibram, attingimos o equilibrio. $O$ que é o excessivo, nas suas manifestações? O universal, que trascende todas as differenças; o synthetico, que funde todas as cousas, para a todas possuir; o illimitado que tem dentro de si o alimento perpetuo da sua perpetua ansia. O portuguez é por temperamento antitradicionalista, anti-portuguez. O portuguez é absolutamente antagonico, como alias, todo o iberico, ao espirito latino, pertença exclusiva da Italia e da França, e que dos Pyrineus para cá não tem razão de ser. É uma das tristes ironias do Destino, sempre ironico, porque a Providencia é immoral, que tenha estado enfeudado ao catholicismo um dos povos menos catholicos do mundo ${ }^{28}$.

\footnotetext{
${ }^{27}$ PASCOAES, Teixeira de Pascoaes, «Os poetas lusíadas» en CASULO, José Carlos, Teixeira de Pascoaes: 1877-1952, Lisboa, Estrategias criativas, 2004, p. 56.

${ }^{28}$ Presenté este inédito pessoano en el Jornal “i” del 17 de Dezembro 2009, p. 46.
} 
Esta excesividad se traduce en la aspiración desmedida, el ansia, el deseo, el hambre en su estado puro dentro de su especificidad no latina, no europea, próxima del espíritu helénico, del espíritu romano, árabe y africano que define lo ibérico: su excesividad, frente a la excesividad exterior propia del español ${ }^{29}$ es una excesividade interior : «é nos sentimentos que somos typicamente desmedidos», una excesividad interior que tanto sufre y goza el poeta lusitano.

Un ansia de lo imposible («Quem adora o impossível/Que esperança pode ter?/Vive numa saudade,/Gosa pena até morrer ${ }^{30}$ ), una presencia de lo ausente que hace que el portugués no pueda vivir en la estrechez de una sola personalidad, religión o filosofía y universalizando su anhelo, su deseo, su saudade de todo lo posible, quiera ser todas las cosas aceptado su destino pagano de herencia heraclítea donde los contrarios se unen y se abrazan, vida y muerte, paganismo y cristianismo, verdad y mentira, identidad y alteridad, realidad y deseo, unidad y pluralidad construyen esta identidad mítica

\footnotetext{
${ }^{29}$ En este sentido, en el de mirar Portugal y la Saudade desde España, es bien conocida la labor unamuniana y no tan visibilizadas las apreciaciones sobre la Saudade portuguesa de Ortega y Ramón Gómez de la Serna:

«La saudade no es un tema portugués, sino el tema portugués por excelencia. Si algún otro puede situarse a su vera es, acaso, la "Descoberta". Ambos polarizan la realidad histórica que es Portugal. Y resulta que son una contraposición: la "Descoberta" es el ansia de irse, la "Saudade" el ansia de volver. La expatriación (una vez) y la re-patriación permanente: antes y después de la Descoberta. Portugal es el "hijo pródigo" de sí mismo. ¿Qué es lo más auténtico, el irse o el volver? Aquello lo hizo una vez: esto lo ha hecho y lo está haciendo siempre. Cada día, cada hora el portugués vuelve. Nótese lo que hay de grave en esto. La Descoberta es un quebrar el horizonte y un buscar el imprevisto más allá, es "mares nunca d'antes navegados", la radical abertura. Saudade es solidificación de todo horizonte dado: un quedar-se en lo viejo, en la costumbre. Una hermetización y el mayor no a la aventura». ORTEGA Y GASSET, José, Saudade, Notas de trabajo, Lisboa, Sete caminhos, 2005, p.22.

«[...] Saudade es una emoción sólo portuguesa; es el secreto de su alma, su característica; es en lo que el alma de los hijos se parece a los padres. -¿Qué es saudade?- hemos preguntado a unos y a otros, y todos nos han dicho algo diferente, como si nos quisieran despistar, como si no nos lo quisieran decir. [...] Atraídos por la indudable armonía de esa palabra, hemos pensado en Galicia, como si lo que conocemos del alma gallega nos pudiese aclarar la palabra, por eso que ha dicho un escritor portugués: "Galicia é a nossa Alsacia" ¿Será saudade una especie de morriña que en su misma Galicia tuviese el gallego como el sentimiento directo de su tierra, algo como una nostalgia que se tuviese, como un sentimiento de más desagarrado amor por las cosas cercanas? Quizá haya algo de esto en saudade; pero esta palabra representa algo más trascendente. En saudade está el amor a las ambiciones inusitadas, está el deseo de lo infinito; en ella hay dolor y ambición, codicia carnal y dolor espiritual, veneración por Venus y por la Virgen Dolorosa; es esa soledad en que siempre se siente el espíritu portugués, tan aislado de Europa y de América y de toda gran parte del mundo; es una añoranza corroedora, pertinaz, dulce al mismo tiempo que encarnizada; es algo de la sangre, que la espesa y la azucara; es la flor de Lusitania. Saudade es el santo y seña con que el corazón del hermano de abre al hermano, es el medio íntimo que tienen los portugueses de reconocerse en la vida privada, es la palabra que da compacta unidad a Portugal y de donde sale esa melancolía portuguesa tan sonriente y tan bondadosa. El que está más lleno de saudade, el que ya podría definir la palabra, es el suicida literario, todos esos artistas que se suicidaron por estar llenos de saudade, imatándose en el momento de encontrar con precisión su significado!». GÓMEZ DE LA SERNA, Ramón, «Cartas desde Portugal», en ID., Pombo, Madrid, Visor, 1999, p. 398-399.

${ }^{30}$ Cit. en PASCOAES, Teixeira de, Verbo Escuro, cit., p. 88.
} 
cosmopolita y antitradicionalista que quiere ser todos los pueblos pasados y futuros. En definitiva ¿Cuál es el futuro añorado del que el portugués y Portugal tiene Saudades? «Esse futuro é sermos tudo ${ }^{31}$ dice Pessoa. Ser nada, ausencia, teatro, máscara para ser todo parece el destino amado por este pueblo de poetas. Un deseo de paradójica vacuidad.

El Quinto Imperio ${ }^{32}$, profetizado por Pessoa siguiendo la tradición quintoimperialista lusa, es por ello un imperio de los sentidos y la creatividad, una refundación mítica de la existencia en la que crear creadores será su máxima expresión. El temperamento meridional, atlántico y su sudoestismo absoluto fundan esta excesividad orgánica del portugués y la búsqueda del equilibrio en este exceso, en esta necesidad de locura, de mito, de ebriedad (la ebriedad es soñar despierto dice bellamente Ortega) haciendo de esta la misión de Portugal, su destino asumido. Soñar todo de todas las maneras posibles, aceptar su agonía, su ser antagónico, destinado a un paganismo superior que le impide sintetizar y que le coloca en una lucha eterna consigo mismo, en un eterno soñar despierto. Ese imperio intemporal que vendrá de nuevo es un país donde la Saudade reina, el pasado se re-crea, lo soñado y lo vivido se hacen indistinguibles, se acepta o ignora la muerte y la palabra tragedia deja de tener el sentido coloquial para recuperar su esencia. Bien sabe esto Eduardo Lourenço:

Contrariamente à lenda, o povo português, ferido como tantos outros por tragédias reais na sua vida coletiva, não é um povo trágico. Está aquém ou além da tragédia. A sua maneira espontânea de se voltar para o passado em geral, e para o seu em particular, não é nostálgica e ainda menos melancólica. É simplesmente saudosa, enraizada com uma tal intensidade no que ama, quer dizer, no que é, que um olhar para o passado no que isso supõe de verdadeiro afastamento de si, um adesão efetiva ao presente como sua condição, é mais da ordem do sonho que do real. É esse lugar de sonho, esse lugar ao abrigo do sonho, esse passado-presente, que a "alma portuguesa" não quer abandonar. Para o não abandonar [...] converteu-se em ilha-saudade. Um lugar sem exterior onde lhe fosse impossível distinguir a realidade do sonho, um porto de onde não se sai, como Ulisses, para defrontar os monstros e a traição dos elementos. [...] Com a saudade não recuperamos apenas o passado como paraíso; inventamo-lo. [...] Na sua ilha-saudade, a

\footnotetext{
${ }^{31}$ PESSOA, Fernando, Sobre Portugal, cit., p. 245.

${ }^{32}$ Se trata de una profecía mesiánica, especialmente instaurada por el fraile jesuita portugués António Vieira que inspirándose en las profecías de Bandarra y en el germen mítico del sebastianismo y el milenarismo profetiza la llegada de un imperio de Dios sobre la tierra capitaneado por un emperador portugués. Um imperio de la paz y la prosperidad. El Quinto imperio tiene herencias mileranistas y apocalípticas. Este mito fue heredado por buena parte de los sebastianistas y especialmente trabajado y defendido por Fernando Pessoa.
} 
um tempo ilha dos mortos e ilha dos amores, como crianças, ignoram a morte. [...] Ninguém morre no país da saudade. Como nos sonhos [...]. ${ }^{33}$

Así el Fado, como expresión musical del Destino y del fatalismo asumido, recupera o mantiene la esencia de lo trágico. El lugar sagrado que tenía la música en las representaciones de la tragedia griega ática. Da lugar, esta íntima experiencia propiciada por el susurro encantador de las guitarras y las melodías vocales a una ruptura del principio de individuación y a un hermanamiento con el Uno primordial, con el Absoluto, con la Voluntad (en perspectiva platónica o nietzscheana) Con la música experimentada como actividad catárquica (Aristóteles) el yo se rompe, se olvida del dolor de la lucidez y del tiempo, se accede a una ilusión donde el yo es de nuevo infantil, pre-reflexivo, impersonal, aquél lugar donde la literatura por esta encarnación de la representación trágica, teatral, adquiere el sagrado instinto de la despersonalización literaria (donde se enmarca la obra pessoana). El yo ya sólo tendrá sentido a través de los otros. La identidad se hará a través de una excesiva voluntad de alteridad que hace indistinguible el yo del otro. $\mathrm{Y}$ eso es la saudade, conciencia de que estamos hechos de presencias, de otredad, de pasado y futuro re-cordado y recreado. ${ }^{34}$ La música es la que da sentido al baile del máscaras que miran hacia el pasado o el futuro, la que hace posible el milagro de irrealizar, de traer a lo presente lo ausente, de convertir la identidad en ausencia ${ }^{35}$ culmen del sentir portugués y del fervor lusíada, destruyendo el tiempo y el espacio, convirtiendo la vida en literatura, en baile de máscaras, deseos y sueños, en ingenuidad y olvido del yo en el recuerdo perpetuo del pasado, del triunfo, de la gloria, del Destino propicio. (Pero también del fracaso y del Imperio perdido)

\footnotetext{
${ }_{33}^{33}$ LOURENÇO, Eduardo, Portugal como Destino, Lisboa, Gradiva, 1999, pp. 93-94.

${ }^{34}$ "A saudade é consciencia dun "eu" que se experimenta determinado por un "outro"; que sabe que o seu ser se realizará na medida en que sexa completado pola presencia doutro ser. Unha vez sentiu na realidade vivida - ou cando menos na realidade presentida33 - a plenitude da unión, o gozo da comunión. Agora o eu síntese aberto a ela, como a unha parte - en oco - de sí mesmo». TORRES QUEIRUGA, Andrés, Nova aproximación a unha filosofía da saudade. Discurso lido o día 20 de xuño de 1980, no acto de súa recepción, polo ilustrísimo señor Don Andrés Torres Queiruga e resposta do excelentísimo señor Don Ramón Piñeiro López,

URL: < http://www.realacademiagalega.org/PlainRAG/catalog/publications/files/Torres Queiruga.pdf $>$ [consultado el 15/10/2011].

35 «Os portugueses não são o único povo que se sente desconhecido, mal conhecido ou decaído do antigo esplendor, real ou imaginário. De algum modo, é o caso de toda a gente e, hoje, até daqueles povos e culturas que, durante séculos, os outros olharam como faróis do mundo. Mas o que surpreende, nos Portugueses, é o facto de parecer terem decidido viver como os cristãos nas catacumbas. Não porque pese sobre eles qualque ameaça efectiva, mas porque não suportam ser olhados por quem ignore ou tenha esquecido a sua vida imaginária. Preferem então o exemplo de Fenrnado Pessoa, ausentar-se de si mesmos e outorgar-se, como ele o fez com insólita fulgurância, o próprio estatuto da ausência. Uma ausência onde tudo e nada são indefinidamente reversíveis». LOURENÇO, Eduardo, Portugal como destino, cit., pp. 89-90.
} 
El fado, música, es decir poesía que acentúa su ritmo hasta hacer sonar su latido, refleja lo deseado haciendo presente lo ausente deseado. El fado traspasa las palabras alegre o triste para mecerse sobre los brazos cálidos de la saudade, donde lo alegre y lo triste, lo idéntico y lo plural, la vida y la muerte se abrazan difuminando sus fronteras en un estado del alma donde la conciencia pre-reflexiva, animal e infantil hace renacer el instinto de un pueblo ${ }^{36}$ que duda entre el amor fati y el hartazgo de este (entre los dos grandes sentidos del fatalismo), que aún dudando entre el suicidio o el deicidio celebra la tragedia de la existencia destejiendo las fronteras entre realidad y deseo, entre ser y no ser conquistando todas las emociones extranjeras. ${ }^{37}$

\footnotetext{
36 «Não me cansarei de afirmar que a Saudade é, em sua última e profunda análise, o amor carnal espiritualizado pela Dor ou o amor espiritual materializado pelo Desejo; é o casamento do Beijo com a Lágrima; é Vénus e a Virgem Maria numa só mulher. É a síntese do Céu e da Terra; o ponto onde todas as forças cósmicas se cruzam; o centro do Universo: a alma da Natureza dentro da alma humana e a alma do homem dentro da alma da Natureza. A Saudade é a personalidade eterna da nossa Raça; a fisionomia característica, o corpo original com que ela há-de aparecer entre os outros Povos. A Saudade é a eterna Renascença, não realizada pelo artifício das Artes, como aconteceu na Itália, mas vivida dia a dia, hora a hora, pelo instinto emotivo dum Povo. A Saudade é a manhã de nevoeiro; a Primavera perpétua, «a leda e triste madrugada» do soneto de Camões. É um estado de alma latente que amanhã será Consciência e Civilização Lusitana...». PASCOAES, Teixeira de, A saudade e o saudosismo: dispersos $e$ opúsculos, Lisboa, A\&A, 1988, p. 39.

${ }^{37}$ Los dos únicos textos explícitamente dedicados al Fado en Fernando Pessoa destacan estas grandes intuiciones que aproximan fado, saudade y tragedia:

«O FADO E A ALMA PORTUGUESA

Toda a poesia - e a canção é uma poesia ajudada - reflecte o que a alma não tem. Por isso a canção dos povos tristes é alegre e a canção dos povos alegres é triste.

$\mathrm{O}$ fado, porém, não é alegre nem triste. É um episódio de intervalo. Formou-o a alma portuguesa quando não existia e desejava tudo sem ter força para o desejar.

As almas fortes atribuem tudo ao Destino; só os fracos confiam na vontade própria, porque ela não existe.

O fado é o cansaço da alma forte, o olhar de desprezo de Portugal ao Deus em que creu e também o abandonou.

No fado os Deuses regressam legítimos e longínquos. É esse o segredo sentido da figura de ElRei D. Sebastião». PESSOA, Fernando, «O Nosso Inquérito sobre o Fado», O Notícias Ilustrado, $2^{\circ}$ série, 44, 14 abr. 1929, p. 14.
}

«Há uma música do Povo,

Nem sei dizer se é um Fado

Que ouvindo-a há um ritmo novo

No ser que tenho guardado

Ouvindo-a sou quem seria

Se desejar fosse ser

É uma simples melodia

Das que se aprendem a viver

Mas é tão consoladora

A vaga e triste canção

Que a minha alma já não chora

Nem eu tenho coração

Sou uma emoção estrangeira,

Um erro de sonho ido

Canto de qualquer maneira

E acabo com um sentido!» 
Conquista de lo extranjero que lleva a preguntarnos hasta qué punto este sentir no es la particularización de un sentir universal. La enyorança catalana, la nostalgia griega, la sehnsucht alemana, la morriña gallega, y sobre todo la dor rumana ponen en duda la particularización absoluta de lo saudoso y permiten afirman la lógica paradójica heraclítea que subyace al pensar poético-trágico. Lo uno y lo múltiple indistinguibles.

Sólo un pueblo que acepta lo trágico, es decir que acepta sin desmenuzar conceptualmente el misterio del existir y su pulsión y contradicción interna hecha de contrarios, mitificando el sentir melancólico universal, la nostalgia de lo absoluto aceptando y celebrando la contingencia y la muerte haciendo de esto su cultura puede particularizar este sentir universal formando una identidad que nace de un sentir universal:

\begin{abstract}
«Habitados a tal ponto pela saudade, os portugueses renunciaram a defini-la. Da saudade fizeram uma espécie de enigma, essência do seu sentimento da existência, a ponto de a transformarem num 'mito'. É essa mitificação de um sentimento universal que dá à estranha melancolia sem tragédia que é o seu verdadeiro conteúdo cultural, e faz dela o brasão da sensibilidade portuguesa». ${ }^{38}$
\end{abstract}

«Talvez só um povo permanentemente distraído de sua existência como tragédia, ou imbuído e inebriado dela a ponto de a esquecer, pudesse tomar por brasão da sua alma a figura da saudade».39

Es todo, en definitiva debido al ser el sentimiento trágico de la vida, en términos unamunianos, clave del pueblo lusíada y por ello del pensar poético ${ }^{40}$ entendido como el bello riesgo de pensar sin dejar de ser poeta, de no poder comprender la filosofía sin un sentimiento trágico que la secunde. De ahí la aceptación de nuestra raíz africana, romana y árabe que imposibilita en nosotros el idealismo platónico: “Africanos somos

PESSOA, Fernando, Poesías inéditas (1919-1930), Lisboa, Ática, 1990, p. 102.

${ }^{38}$ LOURENÇO, Eduardo, Portugal como destino, cit., p. 113.

${ }^{39}$ Ibidem, p. 117.

${ }^{40}$ «O génio lusíada é mais emotivo que intelectual. Afirma e não discute. Quando uma ideia se comove, despreza a dialéctica; e é sendo e não raciocinando que ela prova a sua verdade. A emoção afoga a inteligência, ultrapassando-a como força criadora. E assim, corresponde à nossa superioridade poética, uma inferioridade filosófica. O português não é nada filósofo; a luz do seu olhar alumia mais do que vê; não abrange, num golpe de vista, os conhecimentos humanos, subordinando-os a uma lógica perfeita e nova que os interprete num todo harmonioso. $\mathrm{O}$ português não quer interpretar o mundo nem a vida, contenta-se em vivê-la exteriormente; e tem, por isso, um verdadeiro horror à Filosofia, imaginando encontrá-la em tudo o que não entende. Daí a sua incapacidade construtiva de novas verdades que representam o móbil superior do Progresso». PASCOAES, Teixeira de, Arte de ser português, cit., p. 96. 
Don Miguel. Enemigos de la civilización y la cultura y odiadores de la Idea" dice Ortega a Unamuno. De ahí, que el idealismo portugués y también el español sean idealismos saudosos o quijotescos, un ansia de lo imposible, proyectada hacia el pasado o el futuro, "saudosismo" o "quijotismo" que nos determina como pueblo. Un pueblo sin miedo al mito, a la literatura y a la ensoñación. El logos poético, la lógica poética es clave esencial de la autenticidad de Iberia y todo ello se traduce en el misterio de la Saudade y por ende en el Fado. Y todo este pensar trágico-poético recuperado de nuevo se funda, frente al fracaso del filosofar moderno, contra el yo cartesiano. El Mito, la aceptación providencialista de la historia suponen un yo superado tal como el predicado por Zarathustra. ${ }^{41}$

Y todo como prueba irrefutable de que el verdadero mundo es la música, de que lo aparente y lo verdadero se abrazan, como dice Pascoaes «O real e o imaginário são duas sombras do mesmo corpo ausente ${ }^{42}$, de que, en palabras de poética síntesis borgesiana: "La vida es apariencia verdadera" 43 .

La saudade participa por tanto de la esencia de la Historia de Portugal en el seno del sentir trágico y su aceptación del baile de contrarios, concretamente del querer y del poder, o para decirlo en términos más propios de lo trágico, entre el desear y el recordar ${ }^{44}$.

Esta saudade comprendida como presencia de la ausencia ${ }^{45}$ supone además, sin duda una superación del tiempo y por tanto en cierta medida una aceptación transhistórica de la realidad. Esta superación del tiempo bien puede encontrarse simbolizada en la leyeda de D. Pedro y Doña Inés ${ }^{46}$ donde con claridad el deseo supera y

\footnotetext{
${ }^{41}$ «Yo amo a aquél cuya alma está tan llena que se olvida de sí mismo, y todas las cosas están dentro de él: todas las cosas se transforman así en su ocaso». NIETZSCHE, Friedrich, Así habló Zaratustra, Madrid, Alianza, 2006, p. 40.

${ }^{42}$ PASCOAES, Teixeira de, Verbo Escuro, cit., p. 7.

${ }^{43}$ BORGES, Jorge Luis, Inquisiciones, Madrid, Alianza, 2007. § La nadería de la personalidad, p. 102.

${ }^{44}$ «Em qualquer momento é possível encontrar no pensamento português, que se consubstancia na literatura e no pensar poético, esta oscilação entre o impulso do desejo e o refluxo da lembrança, e há periodos da cultura lusíada em que qualquer deles domina e se cualifica à face da saudade». BOTELHO, Afonso, Da Saudade ao Saudosismo, Lisboa, Instituto de Cultura e Língua Portuguesa, 1990, p. 9.

45 «A saudade é antes de tudo, ausência, apartamento de pessoas, de seres livres que se prenderam. É o vibrar daquela corda de lã (macia e resistente que para D. Duarte simboliza toda a lealdade do amor». Ibidem, p. 30.

${ }^{46}$ Noble gallega, amante de Pedro de Portugal (posteriormente Pedro I) repudiada por la nobleza portuguesa tras su unión con Pedro, su descendencia fue considerada ilegítima. El Rey Alfonso IV la repudió y finalmente fomentó su asesinato. Pedro la declaró y coronó reina después de muerta y según la leyenda hizo besar su mano a los nobles durante la coronación e infligió una cruel venganza contra sus asesinos por lo que se le apodó como el Cruel o el justiciero.
} 
domina al tiempo. Por todo ello no es nada raro comprender las "saudades do futuro" expresadas en las letras de $\operatorname{los}$ fados $^{47}$, o la 'historia del futuro' propuesta por Vieira ${ }^{48}$.

Se trata por tanto del sentimiento metafísico donde enraíza la profecía y la transhistoricidad que supone un regreso eterno a lo ausente (un eterno retorno de lo mismo en términos nietzscheanos) que está paradójicamente siempre presente. Y todo en el seno de una sensibilidad panteísta que acepta que el destino individual está inscrito en buena medida en el colectivo, en el núcleo mismo del estado agónico del ser.

Así nos encontramos ante una narración pre-vista, pre-concebida por los dioses y recogida en la historia de los hombres. Pueblo, por tanto, indeciso en el interpretar el tiempo, póstumo, suicida (en palabras de Unamuno), vencido por la liberación del ser estático. Bien podría haber nacido Heráclito a las orillas del Tajo.

\section{Historia y Destino. Historia y Mito. El pensamiento mítico (El mito del Rey perdido)}

El triunfo del alma sobre el cuerpo está presente en los grandes mitos portugueses. Está presente en el sebastianismo y también en la leyenda sobre Inés de Castro. La imposición de la eternidad a la vida, el imperio del Espíritu la superación del tiempo son telas esenciales del entramado del alma portuguesa. La historia comprendida como trans-historia, como superación de las fronteras entre pasado-presente y futuro a través de la ontología saudosa y la proximidad entre leyenda, narración, mito, epopeya e historia son claves para acercarse al fatalismo portugués y el diálogo prodigioso entre historia y destino que nos ofrece este pueblo hijo del mar y la locura y la alianza con la muerte. La aceptación de la vida como tragedia y por ende como literatura convierte la historia en la narración viva anclada en la conciencia de un pueblo que ha decidido olvidar las fronteras entre verdad y mentira, memoria y olvido, ciencia y poesía, historia y mito, para aceptar el destino colectivo de soñar despiertos eternamente.

Pocos pueblos conocen también lo que significa la palabra Destino, una continua búsqueda de la identidad perdida, quizá una búsqueda eterna, quizá buscar un espejo del tamaño del mundo que revele el propio rostro de un pueblo. El portugués es el pueblo que habitando la absoluta alteridad hace de su identidad una pluralidad infinita de identidades, fundando un nacionalismo cosmopolita que nace de una paradójica ontología de la ausencia (saudosismo, sebastianismo) que hace de la identidad

\footnotetext{
${ }^{47}$ Parece especialmente interesante para nuestro trabajo escuchar el Fado da Sina.

48 «Para a saudade-saudade, o passado vale tanto como o futuro, pois um e outro Nela se acordam ou se eliminam, o que é o mesmo». BOTELHO, Afonso, op. cit., p. 127.
} 
portuguesa un perpetuo errar por los más solitarios desiertos de la id-entidad. De ahí su condición de trágico. Trágico es el hombre y el pueblo que asume el dolor de la lucidez, la lucha entre la vida, el deseo y la razón y sabe que la conciencia es un luchar agónico que revela la fatalidad ${ }^{49}$ de la existencia.

El hecho histórico desde esta perspectiva se convierte en el modelador de las vivencias. En el dios supremo de una concepción religiosa, providencialista, profética de la Historia. La historia se sufre y se disfruta como se sufre y se disfruta la Memoria y el Olvido. Este sentir trágico hace existencialmente explícito el problema de la libertad y pone de manifiesto cómo ésta, la historia, la escrita y la vivida, no existiría sin éste problema clave del pensar trágico. Esta aceptación fatal de la profundidad de lo histórico en el seno de la id-entidad portuguesa es similar a la que encontramos en el pueblo rumano. ${ }^{50}$ Así el pueblo trágico vive en la necesidad de lo histórico y la libertad se convierte en una gran paradoja que nace de la aceptación del destino y la determinación cíclica o lineal del acaecer temporal-existencial. En este punto podemos pensar la relación entre determinismo y fatalismo, aunque sea complicado marcar la frontera delicada que separa ambas intuiciones.

El determinismo, la necesidad racional del hegelianismo, del materialismo científico o de otras teorías filosóficas también nace de la aceptación de un proceso racional de lo histórico y lo social. Ésta concepción supone negar cierto tipo de libertad o en último término aceptar un papel activo de la Historia y cierta pasividad, padecimiento, del sujeto de la historia.

Recordemos aquí la expresión hegeliana: "la libertad es la necesidad comprendida" y pensemos "necesidad" en los términos que aquí manejamos, como determinación. La libertad sería así la aceptación, la comprensión de lo fatal, de lo irremediable, del

\footnotetext{
${ }^{49}$ «Vivir con la conciencia agónica de la fatalidad, de nuestra propia impotencia ante los grandes problemas que no podemos plantearnos sin implicarnos en ellos trágicamente, equivale a enfrentarse directamente con la interrogación capital que se erige ante este mundo». CIORAN, Emile, En las cimas de la desesperación, Barcelona, Tusquets, 2009, p. 123.

${ }^{50}$ «Bueno, yo procedo de Rumanía, circunstancia importante para la comprensión de la historia. Procedo de un país en el que no haces la historia, sino que la padeces simplemente, en el que eres, por tanto, objeto y no sujeto de la historia. En Occidente resulta difícil comprender esa situación. Basta con pensar en todo lo que Occidente, en particular Francia, ha realizado: Francia estuvo durante siglos en el centro de la Historia, Francia era la historia.[...] Hay momentos en la historia en los que el hombre se eleva a la dignidad de sujeto, en que es verdaderamente creador, pero, como yo procedo del Este, soy mucho más propenso a ver en la historia el aspecto pasivo y a hablar de ello. [...] Mi sentimiento profundo me dice que no es el hombre quien ha creado la historia, sino que, al contrario, él mismo es sin duda obra de la historia. [...] El gran problema sigue siendo para mí el de la libertad. Filosóficamente, es insoluble. Y estoy convencido de que, si tuviera una solución, toda la filosofía quedaría sin objeto. Pero es insoluble y es mejor así. Así la cuestión de la libertad en la historia sigue siendo también insoluble. Ese problema es precisamente el que produce la historia.». CIORAN, Emile, Conversaciones, Barcelona, Tusquets, 2010, pp. 191-193.
} 
Fatum racional o mágico. La libertad sería así una alegre mansedumbre ${ }^{51}$, la aceptación de la imposibilidad de pensar el individuo completamente aislado del mundo, la aceptación estoica, pagana, de un destino material, animal, biológico. Recordemos la expresión nietzscheana: "bailar encadenado". Sólo aceptando cierta fatalidad tiene sentido la Historia, la Historia de la Ciencia y la Historia de la Providencia, el mito y la profecía. Toda lógica de lo histórico debe nacer de aceptar cierto fatalismo. ${ }^{52}$

El Determinismo sería así únicamente "la timidez del fatalismo" en palabras de Fernando Pessoa ${ }^{53}$. Esta reflexión nos lleva a pensar en cuán importante es pensar la

${ }^{51} \mathrm{Cfr}$. «Si todos los contenidos de su conciencia natural no se estremecen, esta conciencia pertenece aún en sí al ser determinado; el sentido propio es obstinación, una libertad que sigue manteniéndose dentro de la servidumbre». HEGEL, Georg W. F., Fenomenología del Espíritu, México D.F., FCE, 1994, p. 121.

52 «El hombre hace la historia: a su vez, la historia lo deshace a él. Él es su autor y su objeto, su agente y su víctima. Hasta hoy, pensaba que la dominaba, pero ahora sabe que se le escapa, que se expande en lo insoluble y lo intolerable: una epopeya demente, cuyo desenlace no implica ninguna idea de finalidad. ¿Cómo asignarle una meta? Si tuviese una, sólo la alcanzaría tras haber llegado a su término. Sólo les aprovecharía a los últimos vástagos, a los supervivientes, a los restos, sólo ellos se verían colmados, sólo ellos serían los beneficiarios del ingente número de esfuerzos y de tormentos soportados por el pasado. Visión exageradamente grotesca e injusta. Si queremos a toda costa que la historia tenga un sentido, busquémoslo en la maldición que pesa sobre ella y en ninguna otra parte. El propio individuo aislado sólo puede tener sentido en la medida en que es partícipe de esta maldición. Un genio maléfico preside los destinos de la historia. Aparentemente, ésta carece de meta, peso está gravada con una fatalidad que se le parece y que confiere al devenir un simulacro de necesidad. Es esta fatalidad, y únicamente ella, lo que permite hablar, sin caer en el ridículo, de una lógica de la historia; permite hablar incluso de una providencia, de una providencia especial, [...]». CIORAN, Emile, Desgarradura, Barcelona, Tusquets, 2004, p. 44.

${ }^{53}$ «[...]O que podemos é conceder a alguns indivíduos um ponto de partida melhor do que a outros: isto é, a maneira de condicionar e corrigir a desigualdade do Destino que é a aristocracia. A aristocracia, assim, surge-nos no seu verdadeiro aspecto - é uma libertação. A "sorte", mesmo, é uma libertação. O privilégio é a única forma de liberdade possível no mundo; porque, sendo a liberdade absoluta impossível, a única liberdade possível é a isenção. O povo, modernamente, tomou sobre si o ser defensor do dogma cristão do livre-arbítrio; o povo medieval, mais são, compreendia a liberdade de outra maneira. E, assim, aquilo a que a gente medieva chamava liberdade era a isenção de qualquer coisa, um privilégio qualquer - $\mathrm{o}$ contrário do que modernamente se chama "liberdade". Escolhendo libertar parte dos indivíduos, não podemos entregar essa escolha a nós mesmos, pois, como desconhecemos o destino futuro de cada um, ignoramos a quem deve ser dado um ponto de partida melhor. Entregamos isso, pois, à natureza, apoiando na hereditariedade natural a hereditariedade social. Isto é, fazendo com que as vantagens de ponto de partida de cada indivíduo derivem da situação paterna.

Este critério determinista é aquele em que se apoia o aristocratismo. O espírito científico tem o seu primeiro progresso quando se aplica aos acontecimentos do mundo exterior, propriamente quase do mundo inorgânico (ou orgânico inferior) e elimina a noção de acaso, substituindo-a por a noção de lei natural. Atinge o segundo estádio do seu desenvolvimento quando torna a noção de lei extensiva aos fenómenos superorgânicos e elimina a noção de livre-arbítrio.

Mas só chega à maioridade quando acaba por fim com a noção de acaso por completo, reconhecendo que nada na vida se furta à lei, que, assim como temos uma hereditariedade certa, temos um destino fatal - que desde a nascença está talhado para [:] em que ano, em que mês, em que dia e a que hora, em que casa, de que doença havemos de morrer. O determinismo é apenas a timidez do fatalismo. Todas as civilizações científicas - que são duas, a grega e a árabe - foram profundamente fatalistas. Não concordas com isto? 
Historia en relación continua con el mito, la Ciencia con la poesía, la alquimia, la magia, la profecía y el rito.

La fuerza ontológica, histórica, embrionaria del mito se muestra en el seno del pensar trágico-poético portugués, muy especialmente en Fernando Pessoa. La aceptación de lo ibérico, y por ende de lo portugués, como un grupo civilizacional alejado del seno europeo es clave para comprender la labor genesiaca del mito en el seno del proyecto del mantenimiento, reconstrucción y renovación mítica de la existencia. El mito es la nada que es todo, en las proféticas palabras pessoanas de su Mensagem y en este poder de hacer real lo aparentemente irreal instaura una lógica paradójica donde verdad y mentira se hacen indistinguibles y la creencia es la patria más fuerte. El sentido científico de la historia pierde así fuerza y razón de ser para convertirse en devenir literario (con o sin autor, con o sin argumento fijado). Puede hablarse entonces de realidad mitológica sin incurrir en contradicciones. Así, los grandes mitos universales regularían anhelos aparentemente particulares (del mismo modo que la llamada universalización de la saudade) y también con ello el mito del rey perdido. Este mito, comprendido en tono universalista podría comprenderse como una imitatio Dei, como una creación religiosa (no hay mayor honor que ser un creador de mitos). No es difícil encontrar formulaciones particulares de este tipo de mesianismo. ${ }^{54}$

\section{Algunas conclusiones provisionales}

El mito, en el pueblo portugués, se convierte en una experiencia religiosa, providencial, mistérica, gnóstica que pone de relieve que "en el sebastianismo hay emergente una filosofía teleológica, providencialista y mítica de la historia" 55 y que asimismo el saudosismo conforma la base intelectual y metafísica del sebastianismo.

ANTÓNIO - Concordo. E um esplêndido prefácio para um Tratado de astrologia.

FRANCISCO - A Grécia e os Árabes foram os maiores astrólogos (porque dos Egípcios e dos Caldeus sabemos apenas que o foram). A ciência culmina na Astrologia. $\mathrm{O}$ auge da ciência é o reconhecimento de que nada existe fora da lei: que tudo vive no Destino. A ciência chegará à sua perfeição quando, conhecendo o determinismo como verdade, reconhecer a Astrologia corno ciência como só não reconhecem, aliás, os que nunca a estudaram detidamente, nem sabem que, se nela há erros, não são mais que os erros de diagnóstico na medicina, que ninguém nega que seja uma ciência, ou que tenha uma base científica.». PESSOA, Fernando, Ultimatum e Páginas de Sociologia Política. Fernando Pessoa, Lisboa, Ática, 1980, p. 70. «Cinco Diálogos sobre a Tirania».

${ }^{54}$ Las germanías valencianas, los comuneros castellanos, los catalanes de 1522, Rodrigo, el último rey visigodo, Alfonso I el batallador o Pedro II el católico, Jaime I el conquistador, el Zar ruso Alejandro I, Ogier de Dinamarca, Carlomagno o el propio rey Arturo son algunos de los ejemplos más recurrentes.

${ }^{55}$ QUADROS, António, «Prefácio» en PESSOA, Fernando, Portugal, Sebastianismo e Quinto Imperio, Lisboa, Europa-America, 1986, p. 29. 
Renovar y re-pensar las relaciones entre Pensamiento y Mito, entre Mito e Historia pasa por recuperar su diálogo del que estamos fatalmente constituidos.

La verdad de la mentira ${ }^{56}$, de la ficción, del mito, es irrenunciable para la vida de los hombres y por todo ello irrenunciable para la conciencia de los hombres como comunidad y como especie. Sin los mitos fundadores, que fundan y refundan míticamente la existencia dejamos de ser animales humanos. Es imposible comprender la Historia sin el Mito. En la identidad de los pueblos trágicos, que aceptan el Destino impuesto: el mito, la leyenda, la profecía son estaciones irrenunciables de su tiempo vivido y sentido.

El pueblo portugués está destinado a seguir buscando por mares espirituales nunca dantes navegados su propio rostro, su propio ser mutante. A re-leer las profecías de Bandarra esperando la instauración del Quinto Imperio ${ }^{57}$, el imperio de todos los

${ }^{56}$ «De instinto, a humanidade odeia a verdade, porque sabe, com o mesmo instinto, que não há verdade, ou que a verdade é inatingível. O mundo conduz-se por mentiras; quem quiser despertá-lo ou conduzi-lo terá que mentir-lhe delirantemente, e fá-lo-á com tanto mais êxito quanto mais mentir a si mesmo e se compenetrar da verdade da mentira que criou. Temos, felizmente, o mito sebastianista, com raízes profundas no passado e na alma portuguesa. Nosso trabalho é pois mais fácil; não temos que criar um mito, senão que renová-lo. Comecemos por nos embebedar desse sonho, por o integrar em nós, por o encarnar. Feito isso, cada um de nós independentemente e a sós consigo, o sonho se derramará sem esforço em tudo que dissermos ou escrevermos, e a atmosfera estará criada, em que todos os outros, como nós, o respirem. Então se dará na alma da Nação o fenómeno imprevisível de onde nascerão as Novas Descobertas, a Criação do Mundo Novo, o Quinto Império. Terá regressado El-Rei D. Sebastião.». PESSOA, Fernando, Sobre Portugal, cit.

57 «Assim temos que no Quinto Império haverá a reunião das duas forças separadas há muito, mas de há muito aproximando-se: o lado esquerdo da sabedoria - ou seja a ciência, o raciocínio, a especulação intelectual, e o seu lado direito - ou seja o conhecimento oculto, a intuição, a especulação mística e cabalística. A aliança de D. Sebastião, Imperador do Mundo, e do Papa Angélico figura esta íntima aliança, esta fusão do material e do espiritual, talvez sem separação. E o próprio Segundo Advento, ou nova encarnação de mesmo Adepto em que outrora Deus projectou o seu Símbolo, ou Filho, não faz senão figurar de outro modo esta mesma aliança suprema.

Não é pois para uma absorção mística que avançamos, sendo para a conjugação clara dos dois poderes da Forca, dos dois lados do Conhecimento. Far-se-á a aparente conquista da inteligência material pela espiritual e da espiritual pela material .

De aí o ser o Império Português ao mesmo tempo um império de cultura e o mesmo império universal, que é outra coisa.

A "paz" que o Bandarra diz que haverá em todo o Mundo será a paz de não haver diferenças religiosas, a de "um só deus será conhecido", como ele diz ainda.

E isto tudo durará o tempo que tiver que durar, porque nada há perene ou eterno, e o mesmo Deus que criou este Mundo não: é porventura mais que um de muitos "deuses", criador de um de muitos "universos", misteriosamente coexistentes, todos eles porventura descritíveis como infinitos e eternos. O mistério - di-lo mais alto ocultismo - é maior não só que o Universo, mas que o mesmo Deus.». PESSOA, Fernando, Sobre Portugal, cit., pp. 146-147.

«O Quinto Império. O futuro de Portugal - que não calculo mas sei -está escrito já, para quem saiba lê-lo, nas trovas do Bandarra, e também nas quadras de Nostradamo. Esse futuro é sermos tudo. Quem, que seja português, pode viver a estreiteza de uma só personalidade, de uma só nação, de uma só fé? Que português verdadeiro pode, por exemplo, viver a estreiteza estéril do catolicismo, quando fora dele há que viver todos os protestantismos, todos os credos orientais, todos os paganismos mortos e vivos, fundindo-os portuguesmente no Paganismo Superior? Não 
dioses gobernados por el Fatum, el Imperio del paganismo y la conjugación total del imperio del espíritu y de la materia, de la Razón y la Vida, donde el esotérico, el alquimista y el místico llamarán Frater al científico, al poeta y al navegante.

\section{Referencias bibliográficas}

FRAY BERNARDO DA CRUZ, Chronica d'el-rei D. Sebastião (1587), Escriptorio, 1903. (Original 1587), University of Toronto, Open Library, URL: <http://www.archive.org/stream/chronicadelreidsoocruz\#page/n7/mode/2up> [visitado el 18/09/2011].

FRAY ANTONIO DE SAN ROMÁN DE RIVADENEYRA, Iornada y muerte del Rey Don Sebastian de Portugal, sacada de las obras de Franchi, ciudadano de Genoua, y de otros muchos papeles autenticos, Valladolid, 1603, URL: $<$ http://books.google.es/books?id=m_5rIfV-

fxkC\&lpg=PA166\&ots=lQWTpnmoJ1\&dq=Jornada\%20y\%2omuerte\%2Odel\%20Rey\%2 oDon\%20Sebastian\%20de\%20Portugal\%2C\%20sacada\%2ode\%2olas\%2oobras\%2ode \%20Franchi\%2C\%2Ociudadano\%2Ode\%2oGenoua\%2C\%2Oy\%2ode\%2ootros\%2omuc hos\%2opapeles\%2oautenticos\&pg $=\mathrm{PP}_{5} \# \mathrm{v}=$ onepage\&q\&f=false $>, \quad$ [visitado el 3/10/2011].

DE TARAZONA, Juan Antonio, Historia de Gabriel de Espinosa, pastelero en Madrigal que fingió ser el Rey Don Sebastián de Portugal, 1683, disponible en: Biblioteca Digital de Castilla y León, URL: <http://bibliotecadigital.jcyl.es/i18n/consulta/registro.cmd?id=8990>, [visitado el 10/10/2011].

DE BAENA PARADA, Juan, Epitome de la vida, y hechos de don Sebastian Dezimo Sexto Rey de Portugal y Vnico dente Nombre. Jornadas que hizo à las Conquiftas de Africa, y fu muerte desgraciada. Con Difcursos Efcolafticos, Politicos, Hiftoriales, y Morales, deduzidos de las merma Hiftoria, Madrid, 1692.

queiramos que fora de nós fique um único deus! Absorvamos os deuses todos! Conquistámos já o Mar: resta que conquistemos o Céu, ficando a terra para os Outros, os eternamente Outros, os Outros de nascença, os europeus que não são europeus porque não são portugueses. Ser tudo, de todas as maneiras, porque a verdade não pode estar em faltar ainda alguma coisa! Criemos assim o Paganismo Superior, o Politeismo Supremo! Na eterna mentira de todos os deuses, só os deuses todos são verdade.». PESSOA, Fernando, Ultimatum e Páginas de Sociologia Política, Lisboa, Ática, 1980, pp. 245-246. 
BOUCHOT, Augusto, Historia de Portugal y sus colonias, Barcelona, Luis Taso, 1858.

TEXIER, Hubert, «Pesquisas históricas sobre Sebastião I, Rei de Portugal» (Paris, 1904) en De como o Desejado morreu no exílio, em Limoges (trad. notas y foto de Manuel J. Gandra) en URL: <www.cesdies.net/quinto-imperio-esebastica/fsp/Texier\%2otraducao.pdf> [visitado el 24/o9/2011].

SAMPAIO, Bruno, O Encoberto, Porto, Liv. Moreira Editora, 1904.

D’AZEVEDO, Lucio, A evolução do Sebastianismo, Lisboa, Clássica Editora, 1918.

DE FIGUEIREDO, Antero, D. Sebastião. Rei de Portugal, Paris-Lisboa, Aillaud e Bertrand, 1924.

BROCHADO, Costa, D. Sebastião. O Desejado, Lisboa, Editorial Império, 1941.

VAN DEN BESSELAAR, José, O sebastianismo. História sumária, Lisboa, Instituto de Cultura e Língua Portuguesa, 1987.

LANCIANI, Giulia, "Il sebastianismo: un sogno che nasce come logos», Atti del XVII Convegno Associacione Ispanisti Italiani, Milano, 24-25-26 ottobre 1996, Vol. 1 - Sogno e scrittura nelle culture iberiche, 1998, págs. 339-351.

RIVAS CALVO, Emilio, D'ABREU, Carlos y VELHA, Praça «Alcazarquivir. El enigma (o el rescate del cuerpo d'el rey don Sebastián)», en Revista cultural da cidade da Guarda, Ano X, $\mathrm{n}^{0}$ 21, $1^{\mathrm{a}}$ série (Julho 2007), p. 39-59.

COSTA LOBO, A., Origens do Sebastianismo, Alfagride, Texto, 2011.

GOMES FERREIRA, Augusto, «Quinto Imperio», Lisboa, Antonio Maria Pereira, 1934.

ORTEGA Y GASSET, José, Saudade. Notas de trabajo, Lisboa, Sete caminhos - Ed. José Luis Molinuevo, 2005, p.22. 
PASCOAES, Teixeira de (seudónimo), Arte de ser português, Lisboa, Ed. Roger Delraux, 1978.

PASCOAES, Teixeira de (seudónimo), Verbo escuro, A beira num relámpago, ParisLisboa, Aillaud e Bertrand, 1915.

LOURENÇO, Eduardo, Portugal como Destino seguido de Mitologia da Saudade, Lisboa, Gradiva, 1999.

LOURENÇO, Eduardo, O labirinto da saudade : psicanálise mítica do destino português, Lisboa, Gradiva, 1988.

DE VASCONCELOS, Carolina Michaëlis, A Saudade portuguesa, Lisboa, Guimarães, 1996. (Ed. original, 1914).

PIÑEIRO, Ramón, Filosofia da Saudade, Vigo, Galaxia, 1984.

ANTUNES, Alfredo, Saudade e profetismo em Fernando Pessoa, Universidad de Braga, Fac. Filosofia Braga, 1983.

TORRE QUEIRUGA, Andrés, Nova aproximación a unha Filosofía da Saudade, Discurso de Recepción en la Real Academía Galega, Xulio, 1980, en URL: < http://www.realacademiagalega.org/PlainRAG/catalog/publications/files/Torres\%20 Queiruga.pdf>, [visitado el 7/10/2011].

BOTELHO, Afonso, Da Saudade ao Saudosismo, Lisboa, Instituto de Cultura e Língua Portuguesa, 1990.

QUADROS, António, Poesia e Filosofia do Mito sebastianista, Lisboa, Guimarães, 2001.

DE UNAMUNO, Miguel, Por Tierras de Portugal y España, Madrid, Alianza, 2006.

DE UNAMUNO, Miguel, Del Sentimiento trágico de la vida, Madrid, Alianza, 2003.

PESSOA, Fernando, Mensagem, Lisboa, Antonio Maria Pereira, 1934. 
PESSOA, Fernando, Portugal, Sebastianismo e Quinto Imperio, Lisboa, EuropaAmérica, 1986.

BANDARRA, António Gonçalves Annes, Trovas de Bandarra, Lisboa, Pessoa editor - Babel (Edição de Jorge Uribe), 2010.

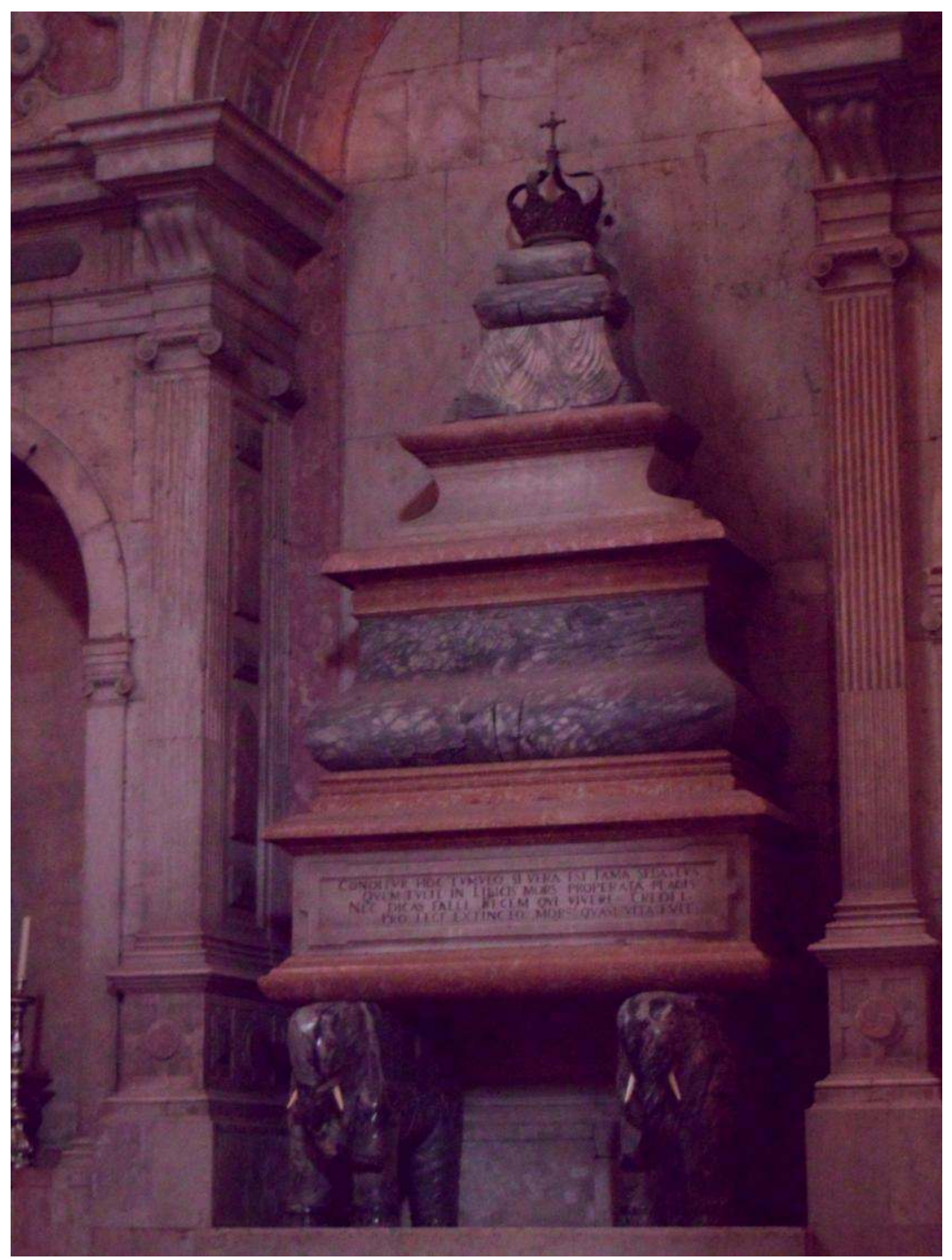

Imagen de la tumba de Sebastião I de Portugal, Mosteiro dos Jerónimos, Lisboa. En el epitafio puede leerse:

"CONDITVR HOC TVMVLO, SI VERA EST FAMA, SEBASTVS, QVEM TVLIT IN LIBICIS MORS PROPERATA PLAGIS. NEC DICAS FALLI, REGEM QUI VIVERE CREDIT, PRO LEGE EXTINCTO MORS QVASI VITA FVIT" 


\section{* El autor}

Pablo Javier Pérez López es Doctor en Filosofía por la Universidad de Valladolid (España). Las temáticas esenciales de sus publicaciones han sido la Infancia, la dialéctica Filosofía-Poesía, el pensamiento trágico, la filosofía de la cultura portuguesa y la dimensión filosófica de Fernando

Pessoa. Entre sus publicaciones en forma de libro pueden destacarse: (ed) Viajes, Literatura y Pensamiento, Valladolid, Uva, 2009; (ed) El pensar poético de Fernando Pessoa, Madrid, Manuscritos, 2010 ; (ed) Filosofía y Literatura: diálogo recobrado, Madrid, Manuscritos, 2011.

URL: < http://studistorici.com/progett/autori/\#PérezLópez >

\section{Per citare questo articolo:}

PÉREZ LÓPEZ, Pablo Javier, «Historia y destino : el fatalismo como identidad nacional lusa», Diacronie. Studi di Storia Contemporanea: Le sembianze di Clio: approcci alla storia, 29/10/2011,

URL:<http://www.studistorici.com/2011/10/29/perez-lopez_numero_8/ >

Diacronie Studi di Storia Contemporanea $\beta$ www.diacronie.it

Risorsa digitale indipendente a carattere storiografico. Uscita trimestrale. redazione.diacronie@hotmail.it

Comitato di redazione: Marco Abram - Giampaolo Amodei - Jacopo Bassi - Luca Bufarale - Alessandro Cattunar - Alice De Rensis Barbara Galimberti - Deborah Paci - Fausto Pietrancosta - Martina Sanna - Matteo Tomasoni - Luca Zuccolo 